\title{
Validitas dan Praktikalitas Modul Titrasi Asam dan Basa Berbasis Inkuiri Terbimbing dilengkapi Soal-Soal Tipe HOTS
}

\section{Validity and Practicality of Guided Inquiry-Based Acid and Base Titration Modules Equipped With HOTS Type Questions}

\author{
E F Asda ${ }^{1}$ and Iryani ${ }^{*}$ \\ ${ }^{1}$ Pendidikan Kimia, Universitas Negeri Padang, Jl. Prof. Dr. Hamka, Air Tawar Barat, \\ Padang Utara, Sumatera Barat, Indonesia 25171 \\ *iryaniachmad62@gmail.com
}

\section{ARTICLE INFO}

Received 03 January 2020

Revised 21 January 2020

Published 06 February 2020

\begin{abstract}
This study aims to determine the validity and practicality categories of the modules that have been produced. This type of research is classified as a Plomp model which has three stages, preliminary research, prototype formation and assessment. The instruments used were validation and practicality sheets in the form of questionnaire sheets. The products produced were tested by 5 validators consisting of 2 chemistry majors at FMIPA UNP and 3 teachers from MAN 2 Pesisir Selatan and practicality tests conducted by 2 chemistry teachers and 30 students of class XI MIPA MAN 2 Pesisir Selatan. Based on the validation results obtained kappa moment value ( $k$ ) of 0.87 , then the practicality of the teacher and practicality of students obtained an average value of kappa moments $(k)$ of 0.85 and 0.91 . The value obtained shows that the module produced is very valid and practical.
\end{abstract}

\section{KEYWORDS}

Acid \& Base Titration, Guided Inquiry, Modules, Plomp Model

\begin{abstract}
ABSTRAK
Penelitian ini bertujuan untuk menentukan kategori validitas dan praktikalitas dari modul yang telah dihasilkan. Jenis penelitian yang dilakukan tergolong model Plomp yang mempunyai tiga tahapan, penelitian pendahuluan, pembentukan prototipe dan assesmen. Instrumen yang digunakan yaitu lembar validasi dan praktikalitas berupa lembaran angket. Produk yang dihasilkan dilakukan uji validitas oleh 5 orang validator terdiri dari 2 orang dosen jurusan kimia di FMIPA UNP dan 3 orang guru dari MAN 2 Pesisir Selatan serta uji praktikalitas dilakukan oleh 2 orang guru kimia dan 30 orang siswa kelas XI MIPA MAN 2 Pesisir Selatan. Berdasakan hasil validasi diperoleh nilai moment kappa (k) sebesar 0,87 , selanjutnya praktikalitas guru dan praktikalitas siswa diperoleh nilai rata-rata momen kappa $(\mathrm{k})$ sebesar 0,85 dan 0,91 . Nilai yang diperoleh menunjukan bahwa modul yang dihasilkan sangat valid dan praktis.
\end{abstract}

KATA KUNCI

Model Plomp, Modul, Inkuiri Terbimbing, Titrasi Asam \& Basa 


\section{PENDAHULUAN}

Pada Kurikulum 2013 revisi 2018 mencanangkan agar dalam proses pembelajaran peserta didik terlibat aktif (Student Center) sehingga mampu melatih kemampuan berpikir tingkat tinggi atau High Order Thinking Skill (HOTS) ${ }^{[1]}$. Untuk merealisasikan hal tersebut maka guru harus menerapkan proses pembelajaran berorientasikan pada pendekatan saintifik, yang terdiri dari beberapa model pembelajaran yaitu pembelajaran berbasis penelitian atau penemuan sebuah konsep (discovery/inquiry learning) kemudian pembelajaran yang berorientasikan pemecahan suatu masalah (Problem Based Learning) dan pembelajaran yang berorientasikan untuk menghasilkan suatu karya (project based learning) ${ }^{[2]}$. Dalam penelitian digunakan salah satu model pembelajaran Inkuiri terbimbing.

Pembelajaran yang menggunakan model inkuiri terbimbing terbagi atas 5 tahap yaitu orientasi, eksplorasi, pembentukan konsep, aplikasi dan penutup ${ }^{[3]}$. Penggunaan model pembelajaran berbasis inkuiri terbimbing merupakan suatu proses pembelajaran yang aktivitasnya dipusatkan pada peserta $\operatorname{didik}^{[4]}$. Proses pembelajaran dengan menerapkan inkuiri terbimbing akan lebih memudahkan peserta didik jika proses pembelajaran tersebut didukung dengan suatu bentuk bahan ajar. Modul merupakan salah satu dari bentuk bahan ajar yang digunakan dalam proses belajar-mengajar yang bertujuan agar peserta didik dapat belajar secara mandiri dengan bantuan seorang guru maupun tidak ada bimbingan seorang guru, sehingga modul lebih baik dilengkapi dengan petunjuk penggunaan sebagai pedoman saat belajar mandiri. Proses pembelajaran dengan menggunakan bahan ajar berupa modul memungkinkan peserta didik dapat melatih kecepatan dalam belajar terkhususnya dalam menyelesaikan suatu KD jika dibandingkan dengan peserta didik yang tidak menggunakan modul dalam pembelajaran, maka dari itu modul yang dikembangkan harus mampu menjelaskan $\mathrm{KD}$ yang hendak dicapai oleh peserta didik dan penyajian dilakukan dengan tampilan yang menarik minat belajar peserta didik.

Bahan ajarmodulberbasis inkuiriterbimbingini dapat mempermudah dan meningkatkan kecepatan belajar dari peserta didik dalam mempelajari ilmu kimia dan melatih peserta didik dalam berpikir kritis dalam menemukan konsep sendiri ${ }^{[5]}$. Salah satu materi dari pembelajaran kimia yaitu materi titrasi asam dan basa, materi ini merupakan materi lanjutan dari materi asam dan basa yang dipelajari oleh kelas XI SMA/MA pada semester genap. Materi titrasi asam dan basa banyak mengandung fakta, konsep dan prosedur.

Pembelajaran yang menggunakan modul inkuiri terbimbing dapat memberikan pengaruh positif terhadap hasil belajar dari peserta didik. Peningkatan hasil belajar dari peserta didik dengan penggunaan modul berbasis inkuiri terbimbing dipengaruhi oleh beberapa faktor salah satunya, yaitu model inkuiri terbimbing menuntun dan melatih peserta didik untuk menemukan dan memahami sebuah konsep dari pertanyaan-pertanyaan kunci yang disediakan. Sehingga peserta didik diharapkan mampu melatih kemampuan berpikir tingkat tingginya atau berpikir kritis, hal itu diperkuat dengan modul inkuiri terbimbing juga dilengkapi dengan soal-soal tipe HOTS. Berpikir kritis atau berpikir tingkat tinggi merupakan sebuah kemampuan berpikir yang tidak hanya dilakukan untuk mengingat (recall), mengulangi pernyataan (restate), atau mengambil sebuah kesimpulan tanpa melakukan pengolahan terlebih dahulu (recite). Berpikir kritis atau berpikir tingkat tinggi dapat dilatih dan ditingkatkan dengan menerapkan soal-soal tipe HOTS pada tahapan asesmen dengan tujuan untuk mengukur kemampuan: 1) menghubungkan suatu konsep ke sebuah konsep lainnya, 2) memproses informasi dan menerapkannya, 3) mengaitkan berbagai informasi yang berbeda-beda, 4) menggunakan informasi yang diterima dalam menyelesaikan sebuah masalah, dan 5) menelaah ide dan informasi yang didapat secara kritis $^{[4]}$.

Pengembangan bahan ajar berbasis inkuiri terbimbing telah dilakukan oleh beberapa peneliti sebelumnya dan telah diuji kevalidan dan kepraktisannya. Penelitian dengan judul $A$ study on The Effect of Guide Inquiry Teaching Method on Student Achievement in Logic mengambil kesimpulan yaitu proses pembelajaran dengan menggunakan inkuiri terbimbing mampu meningkatkan hasil dari belajar peserta didik dibandingkan ketika menggunakan cara yang konvensional ${ }^{[6]}$. Selanjutnya penelitian tentang penggunaan bahan ajar berupa modul berbasis inkuiri terbimbing mampu mempengaruhi hasil belajar dari peserta didik menjadi lebih positif ${ }^{[7]}$.

Hasil wawancara dengan guru dan penyebaran angket kepada peserta didik yang telah dilakukan di MAN 1 Pesisir Selatan dan MAN 2 Pesisir Selatan diperoleh hasil yaitu bahan ajar yang masih digunakan guru di sekolah yaitu berupa buku paket, LKPD dan power point, yang belum dilengkapi dengan soal-soal tipe HOTS dan penyajiannya belum mencakup tiga level representasi kimia. Penyajian soal-soal tipe HOTS bertujuan untuk melatih peserta didik untuk lebih aktif dalam pembelajaran sehingga peserta didik dapat melatih kemampuan berpikir tingkat tingginya.

\section{METODE}

Jenis dari penelitian yang dipakai merupakan penelitian dan pengembangan atau Research and Development. Model pengembangannya yaitu pengembangan dari model Plomp yang dikembangkan oleh Tjeered Plomp, model Plomp mempunyai 3 tahapan yaitu tahap penelitian awal, tahap pembentukan prototipe dan tahap penilaian $^{[8]}$. Penelitian ini dilakukan pada tahap pengujian validitas dan praktikalitas terhadap modul yang dikembangkan. Subjek penelitian ini terdiri 
dari 2 orang dosen dari kimia FMIPA UNP, 3 orang guru dari MAN 2 Pesisir Selatan serta peserta didik MAN 2 Pesisir Selatan.

Tahap penelitian awal (preliminary research), yang dilakukan pada tahap preliminary research yaitu (a) menganalisis kebutuhan yang dilakukan dengan mewawancarai guru kimia MAN 1 dan 2 Pesisir Selatan dan menyebarkan angket terhadap peserta didik; (b) analisis konteks yaitu mengidentifikasi materi-materi pokok yang harus dikuasai peserta didik pada materi titrasi asam dan basa, analisis yang dilakukan berupa analisis dari KD yang dirumuskan menjadi indikator dan tujuan pembelajaran; (c) studi literatur merupakan kegiatan mencari dan memahami semua sumber yang berkaitan terhadap materi pengembangan penelitian yang dilakukan; (d) pengembangan kerangka konseptual yaitu melakukan analisis konsep-konsep esensial yang harus ada pada modul yang dikembangkan.

Tahap pembentukan prototipe (prototyping stage), kegiatan yang dilakukan pada tahap pembentukan prototipe yaitu (a) prototipe I, dilakukan perancangan dan penetapan komponenkomponen dari sebuah modul yang akan digunakan pada produk yang akan dikembangkan; (b) prototipe II, dilakukan evaluasi formatif yang merupakan sebuah evaluasi terhadap prototipe I yang telah dihasilkan, dan hasil revisinya dinamakan prototipe II; (c) prototipe III, dilakukan pengujian satusatu atau one to one evaluation dan penilaian dari para ahli atau expert review, pengujian satu-satu dilakukan dengan cara mewawancarai 3 orang peserta didik sebagai responden.

Validitas merupakan aspek penting dan pertama dalam menentukan kualitas produk ${ }^{[6]}$. Validasi dilakukan untuk menguji tingkat kategori kevalidan dari suatu modul yang dikembangkan. Validasi dilakukan oleh dosen dari kimia FMIPA UNP dan orang guru SMA/MA, setelah dilakukan tahap ini dan melakukan revisi didapatkan hasil prototipe III. Analisis validitas isi dan desain dilakukan berdasarkan categorical judgments dari Boslaugh. Pada categorical judgments, diberikan lembar validasi berupa angket yang kemudian validator akan memberikan penilaian pada masing-masing pernyataan. Instrumen yang digunakan pada penelitian berupa lembar validasi ${ }^{[8]}$. Prototipe IV didapat dari hasil dari revisi validator.

Selanjutnya tahap penilaian (assesment phase) dilakukan uji lapangan untuk mengetahui tingkat praktikalitas dari modul. Data validasi dan praktikalitas yang dinilai validator dan siswa dalam praktikalitas akan dianalisis menggunakan formula kappa cohen di bawah ini.

$$
\text { momen kappa }(k)=\frac{\rho_{0}-\rho_{e}}{1-\rho_{e}}
$$

$k=$ nilai dari momen kappa

$\rho_{e}=$ proporsi yang terealisasi

$\rho_{0}=$ proporsi yang tidak terealisasi
Tabel 1. Kategori kevalidan dan praktikalitas berdasarkan Momen kappa (k)

\begin{tabular}{c|c} 
Interval & Kategori \\
\hline$<0,00$ & Tidak valid \\
\hline $0,00-0,20$ & Sangat rendah \\
\hline $0,21-0,40$ & Rendah \\
\hline $0,41-0,60$ & Sedang \\
\hline $0,61-0,80$ & Tinggi \\
\hline $0,81-1,00$ & Sangat tinggi
\end{tabular}

\section{HASIL DAN DISKUSI}

3.1. Tahap Penelitian Awal (Preliminary research)

Tahap penelitian awal mempunyai beberapa bagian tahapan yaitu tahap melakukan analisis kebutuhan, analisis konteks, studi literatur dan juga kerangka konseptual.

\subsubsection{Analisis kebutuhan.}

Berdasarkan hasil angket dari siswa dan wawancara dengan guru, dapat diambil hasil dari observasi yaitu; (1) banyak peserta didik yang menganggap materi titrasi asam dan basa sulit; (2) bahan ajar yang dipakai di sekolah berupa buku paket dan LKPD yang belum dilengkapi dengan soal-soal tipe HOTS; (3) bahan ajar yang digunakan tidak menggunakan model pembelajaran inkuiri terbimbing dan dari segi penyajian materi masih kurang menarik; (4) Peserta didik mempunyai kemampuan akademik yang berbeda.

\subsubsection{Analisis konteks.}

Tahap analisis konteks dilakukan analisis kurikulum dan analisis silabus. Hasil dari analisis kurikulum ditemukan bahwa kurikulum 2013 revisi 2018 yang menggunakan pendekatan saintifik mengharuskan proses pembelajaran berpusat pada peserta didik (student center) agar peserta didik mampu melatih keterampilan berpikir tingkat tinggi. Selanjutnya adalah analisis silabus, analisis silabus ini dilakukan dengan cara menganalisis kompetensi dasar dan menguraikannya menjadi indikator pencapaian kompetensi serta tujuan pembelajaran. Kompetensi dasar yang dianalisis adalah kompetensi dasar 3.13 menganalisis data hasil berbagai jenis titrasi asam dan basa 4.13 menyimpulkan hasil analisis data percobaan titrasi asam dan basa. Berdasarkan kompetensi dasar tersebut dirumuskan indikator pencapaian kompetensi yaitu 1) menganalisis konsentrasi suatu asam atau basa melalui percobaan titrasi asam dan basa, 2) menganalisis suatu $\mathrm{pH}$ asam atau basa berdasarkan data hasil percobaan, 3) membuat kurva titrasi asam dan basa berdasarkan data hasil percobaan, 4) melakukan percobaan titrasi asam dan basa, 5) menganalisis kadar suatu 
senyawa melalui percobaan titrasi asam dan basa, 6) menyimpulkan data hasil percobaan titrasi asam dan basa. Berdasarkan indikator pencapaian kompetensi yang telah diuraikan dapat dirumuskan tujuan pembelajaran yang harus dicapai peserta didik dalam mempelajari materi titrasi asam dan basa.

\subsubsection{Studi literatur.}

Tahap studi literatur telah dilakukan dengan mencari dan memahami sumber-sumber materi terkait penelitian yang dilakukan, selain jurnal bukubuku dan beberapa sumber lainnya juga digunakan untuk penelitian yang dilakukan. Diantaranya (1) komponen-komponen yang digunakan pada modul dirujuk dari kemendiknas 2010; (2) konten (isi materi) yang terdapat pada modul dirujuk dari buku-buku perguruan tinggi dan buku kimia SMA; (3) model pembelajaran inkuiri terbimbing dan keterampilan berpikir tingkat tinggi dirujuk dari jurnal, buku dan sumber lainnya seperti internet.

\subsubsection{Kerangka konseptual.}

Tahap ini bertujuan untuk melihat konsepkonsep penting yang harus terdapat pada modul. Dari hasil analisis konsep yaitu mencari konsepkonsep utama yang harus dipelajari peserta didik dapat diketahui konsep-konsep apa saja yang harus terdapat pada modul.

\subsection{Tahap Pembentukan Prototipe (Prototyping stage)}

Tahap pembentukan prototipe menghasilkan empat prototipe, sebelum dihasilkan prototipe final atau produk akhir, setiap dihasilkan prototipe dilakukan evaluasi dan jika dibutuhkan maka dapat di dilakukan revisi. Rincian hasil dari tahapan pembentukan prototipe ini di uraikan sebagai berikut.

\subsubsection{Prototipe I.}

Prototipe I merupakan hasil dari perancangan yang disesuaikan dengan penelitian awal. Prototipe I yang dihasilkan berupa modul yang terdiri dari beberapa komponen diantaranya yaitu cover, kata pengantar, daftar isi, daftar gambar, daftar tabel, peta konsep, petunjuk penggunaan modul, kompetensi inti, kompetensi dasar, indikator pencapaian kompetensi, tujuan pembelajaran, lembar kegiatan, lembar kerja, lembar evaluasi, kunci lembar kerja dan kunci lembar evaluasi. Modul yang dihasilkan mempunyai dua aktivitas yaitu aktivitas kelas dan aktivitas laboratorium yang menggunakan tahap dari pembelajaran inkuiri terbimbing yaitu, tahap orientasi, eksplorasi, pembentukan konsep, aplikasi dan penutup. Rincian Hasil dari masing-masing tahapan inkuiri terbimbing adalah sebagai berikut.

\subsubsection{Tahap orientasi.}

Tahap orientasi dicantumkan indikator atau tujuan pembelajaran yang harus dicapai peserta didik, motivasi yang berkaitan dengan materi berfungsi untuk meningkatkan minat dan ketertarikan peserta didik terhadap materi yang akan dipelajari, materi pra-syarat merupakan materi yang harus dikuasai peserta didik sebelum mempelajari materi yang akan dibahas, keterkaitan materi yang dibahas dengan materi lain.

\subsubsection{Tahap eksplorasi dan pembentukan konsep.}

Tahap ini terdiri dari ekspor yang mana peserta didik diberikan beberapa model dan diminta untuk mengamati dan menganalisis model yang diberikan agar dapat menjawab pertanyaan kunci yang telah tersedia. Tahap pembentukan konsep terjadi saat peserta didik dapat menjawab pertanyaan kunci yang sesuai dengan model yang diberikan. Pertanyaan kunci ini disusun dari ranah kognitif terendah sampai ke yang tertinggi, dengan menjawab pertanyaan-pertanyaan kunci ini peserta didik akan dapat menemukan suatu konsep terkait materi yang sedang dipelajari.

\subsubsection{Tahap aplikasi.}

Merupakan tahap saat konsep yang telah ditemukan peserta didik dari tahap eksplorasi dan pembentukan konsep diperkuat pada tahap aplikasi dengan cara menyajikan soal-soal latihan pada modul, soal latihan tersebut dibuat berbentuk esai yang dibuat dari ranah kognitif C4 dengan tujuan untuk melatih keterampilan berpikir tingkat tinggi peserta didik.

\subsubsection{Tahap penutup.}

Pada tahap ini peserta didik menyimpulkan materi yang dipelajari. Prototipe I yang dihasilkan terdiri dari aktivitas kelas dan aktivitas laboratorium. Prototipe I yang dihasilkan dilengkapi dengan soalsoal tipe HOTS bertujuan untuk dapat meningkatkan keterampilan dari berpikir tingkat tinggi peserta didik.

\subsubsection{Prototipe II.}

Tahap pembentukan prototipe 2 dilakukan evaluasi formatif atau evaluasi diri sendiri yang dilakukan pada prototipe I yang telah dihasilkan, berdasarkan evaluasi yang telah dilakukan disimpulkanbahwa prototipe Iyang dihasilkan masih memerlukan revisi, ada beberapa komponen modul yang ditambahkan setelah melakukan evaluasi diri sendiri diantaranya kunci jawaban lembaran kerja dan kunci jawaban lembaran evaluasi. Hasil dari evaluasi dan revisi prototipe I ini dinamakan dengan prototipe II.

\subsubsection{Prototipe III.}

Tahap prototipe 3 dilakukan pengujian satusatu dan penilaian ahli terhadap produk yang dikembangkan. Hasil dari pengujian satu-satu yang dikerjakan didapatkan bahwa peserta didik memberikan respon positif pada modul yang sedang dikembangkan, peserta didik menilai modul yang dikembangkan sudah menarik dari segi penyajian maupun dari segi konten. Setelah dilakukan uji coba satu-satu maka dilakukan penilaian ahli. Penilaian ahli ini bertujuan untuk melihat bagaimana tingkat kevalidan modul yang dikembangkan, berdasarkan teori suatu produk akan dikatakan valid atau 
tidak didasarkan pada pengujian dan penilaian kevaliditasan, komponen penilaian validitas produk adalah sebagai berikut;

3. Komponen kelayakan isi

(a) Penyesuaian terhadap KD; (b) Penyesuaian terhadap perkembangan peserta didik; (c) Penyesuaian terhadap bahan ajar yang diperlukan; (d) kebenaran dari substansi terhadap materi; (e) manfaat yang dapat menambah wawasan; (f) Penyesuaian terhadap nilai moral, dan nilai sosial yang berlaku.

4. Komponen kebahasaan

(a) Keterbacaan; (b) Informasi yang ada harus jelas; (c) kesesuaian terhadap kaidah bahasa Indonesia yang baik dan benar; (d) penggunaan bahasa harus efektif dan juga efisien

5. Komponen Penyajian

(a) tujuan dari indikator yang akan dicapai jelas; (b) urutan penyajian; (c) motivasi dan menarik; (d) Interaksi terhadap peserta didik atau pemberian stimulus dan respon; (e) informasi yang disajikan lengkap.

6. Komponen Kegrafikan

(a) Pemilihan font dari jenis dan ukuran yang digunakan; (b) tata letak; (c) ilustrasi, gambar, dan foto; (d) desain dari tampilan.

Hasil dari analisis data validasi modul terhadap beberapa aspek dapat dilihat pada Gambar 1.

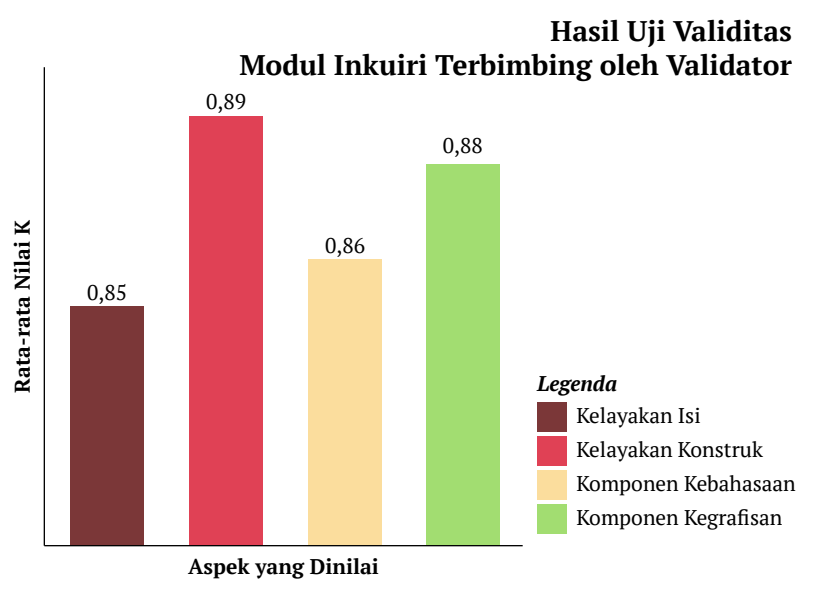

Gambar 1. Rata-rata hasil analisis data validitas yang dinilai oleh validator

Berdasarkan gambar di atas terlihat bahwa kelayakan isi dari modul adalah sebesar 0,85 dengan tingkat kevalidan yang sangat tinggi, kelayakan isi adalah penilaian terhadap produk bahan ajar yang dikembangkan berdasarkan kurikulum yang relevan dan teoritik yang kuat. Kelayakan konstruk 0,89 dengan tingkat kevalidan yang sangat tinggi, kelayakan konstruk merupakan penilaian konsistensi internal yang terdapat pada bahan ajar. Komponen kebahasaan 0,86 dengan tingkat kevalidan yang sangat tinggi, komponen kebahasaan merupakan penggunaan bahasa yang jelas dan mudah dipahami dengan menggunakan kaidah Bahasa Indonesia. Komponen kegrafisan 0,88 . Jika diartikan berdasarkan kategori momen kappa (k) maka kelayakan isi kategorinya sangat tinggi, kelayakan konstruk merupakan penilaian terhadap tata letak, jenis serta ukuran huruf dan warna yang jelas dan menarik secara keseluruhan yang terdapat pada bahan ajar. Kategori kevalidan yang didapat berdasarkan masing-masing aspek yang dinilai mempunyai kevalidan sangat tinggi dengan rata-rata nilai momen kappa yang didapat adalah 0,87 .

\subsubsection{Prototipe IV.}

Tahap prototipe IV didapat berdasarkan revisi yang telah dilakukan dari Prototipe III yang telah menghasilkan modul yang valid dan praktis.

\subsection{Tahap penilaian (Assessment Phase)}

Praktikalitas suatu bahan ajar dapat dilihat dari beberapa aspek-aspek yaitu, (a) Kemudahan penggunaan, (b) Waktu yang diperlukan dalam pelaksanaan sebaiknya singkat, cepat dan tepat, dan (c) Manfaat dan daya tarik dari bahan ajar.

Hasil dari praktikalitas dari aspek-aspek tersebut dapat dilihat pada Gambar 2.

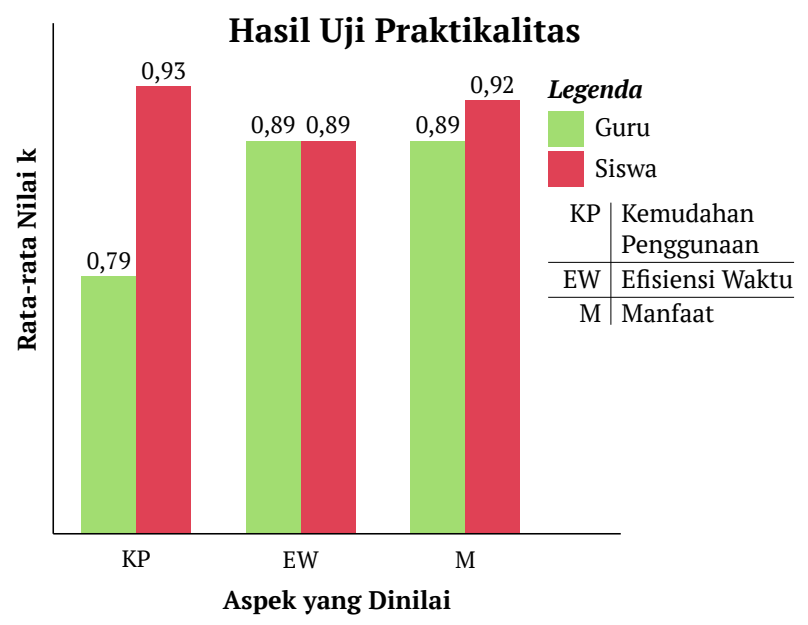

Gambar 2. Rata-rata hasil analisis data praktikalitas guru dan siswa

Berdasarkan analisis data praktikalitas yang didapat dari Guru dan Peserta didik didapat nilai secara berturut-turut yaitu 0,79 dan 0,93 untuk kategori kemudahan penggunaan, 0,89 dan 0,89 untuk kategori efisiensi waktu, 0,88 dan 0,92 untuk kategori manfaat.

\section{SIMPULAN}

Berdasarkan penelitian yang telah dilakukan, dapat disimpulkan bahwa modul titrasi asam dan basa berbasis inkuiri terbimbing yang dihasilkan dengan menggunakan model pengembangan Plomp memiliki tingkat kevalidan sangat tinggi dengan nilai momen kappa (k) 0,87. Sedangkan untuk praktikalitas Guru didapat nilai momen kappa (k) 0,85 dan 0,91 untuk nilai momen kappa dari praktikalitas peserta didik.

\section{REFERENSI}

1. RI P. Perubahan Atas Peraturan Menteri Pendidikan Dan Kebudayaan Nomor 59 Tahun 2014 Tentang Kurikulum 2013 Sekolah Menengah Atas/Madrasah Aliyah. 2018. 
2. RI P. Peraturan Menteri Pendidikan Dan Kebudayaan Nomor 22 Tahun 2016 Tentang Standar Proses Pendidikan Dasar Dan Menengah.

3. Hanson DM. Designing Process-Oriented Guided-Inquiry Activities. Pacific Crest 2005;(2nd edition).

4. Sanjaya W. Strategi Pembelajaran Berorientasi Standar Proses Pendidikan. Jakarta: Kencana Prenada Media Group; 2006.

5. Sugiyono. Metode Penelitian Pendidikan. Bandung: Alfabeta; 2017.

6. Prastowo A. Panduan Kreatif Membuat Bahan Ajar Inovatif. Yogyakarta: Diva Press; 2011.

7. Iryani, Mawardi and A. Pengaruh Penggunaan Lks Berbasis Inkuiri Terbimbing Terhadap Hasil Belajar Siswa Untuk Materi Koloid Kelas XI SMAN 1 Batusangkar. Eksakta 2016;1.

8. Boslaugh S dan PAW. Statistics in a Nutshell, a desktop quick reference. Beijing, Cambridge, Famham, Köln, Sebastopol, Taipei,Tokyo: O'reilly; 